\title{
Effect of elevated summer temperatures on gonadal steroid production, vitellogenesis and egg quality in Tasmanian female Atlantic salmon (Salmo salar L.)
}

\author{
H.R. KING ${ }^{*}, \dagger$, N.W. PANKHURST ${ }^{\dagger}$, M. WATts ${ }^{\dagger}$ AND P.M. PANKHURST ${ }^{\dagger}$ \\ * Salmon Enterprises of Tasmania Pty. Ltd., P.O. Box 1, Wayatinah, Tasmania, Australia 7140 \\ and ${ }^{\dagger}$ School of Aquaculture, Tasmanian Aquaculture \& Fisheries Institute, University of \\ Tasmania, Locked bag 1-370, Launceston, Tasmania, Australia, 7250
}

To assess the effect of exposure to elevated water temperatures on vitellogenesis and egg quality in Tasmanian female Atlantic salmon (Salmo salar L.), groups of fish were maintained at 14,18 and $22^{\circ} \mathrm{C}$ for 3 months from mid-summer (January). Blood plasma levels of $17 \beta$-estradiol $\left(\mathrm{E}_{2}\right)$, testosterone $(\mathrm{T})$, cortisol and vitellogenin $(\mathrm{Vtg})$ were measured at regular intervals and in autumn (April) temperatures were reduced to $8^{\circ} \mathrm{C}$ to facilitate spawning and egg incubation. Maintenance at $22^{\circ} \mathrm{C}$ during vitellogenesis was associated with a general reduction in plasma $E_{2}$ levels and an early reduction in plasma Vtg levels relative to those observed in fish held at 14 and $18^{\circ} \mathrm{C}$. Significantly reduced oocyte diameters in ova from fish held at $22^{\circ} \mathrm{C}(5.4 \mathrm{~mm}$ c.f. $5.7 \mathrm{~mm})$ confirmed reduced maternal investment and an increase in the incidence of previously undescribed chorion damage suggested that zonagenesis may also have been impaired. As a result, the fertility and survival of ova from fish exposed to $22^{\circ} \mathrm{C}$ ( $69 \%$ and $42 \%$ respectively) were significantly reduced relative to those of ova from fish maintained at $14^{\circ} \mathrm{C}(93 \%$ and $86 \%)$ and $18^{\circ} \mathrm{C}(86 \%$ and $84 \%)$.

Key words: vitellogenesis; $17 \beta$-estradiol; testosterone; vitellogenin; temperature; salmon.

\footnotetext{
* Author to whom correspondence should be addressed: Tel.: +61 36289 3280; fax: +61 36289 3290; email: harry_king@saltas.com.au
} 


\section{INTRODUCTION}

Reproductive development in female salmonids commences many months or even years prior to final oocyte maturation (FOM) and ovulation (Billard, 1985). Vitellogenesis, the phase of rapid ovarian growth which is characterised by the hepatic production and ovarian uptake of the yolk protein precursor vitellogenin (Vtg) (reviewed by Specker \& Sullivan, 1994), in turn occurs over several months of the female reproductive cycle (Billard, 1985). During vitellogenesis, individual oocytes may increase in size by several hundred-fold and Vtg can account for over $90 \%$ of final oocyte volume (reviewed by Tyler, 1991; Tyler et al., 2000). Since salmonids are generally recognised as autumn and winter spawners (reviewed by Scott, 1990), much of the vitellogenic oocyte growth takes place during summer and early autumn (eg. Bromage \& Cumaranatunga, 1988; Tyler et al., 1990; Estay et al., 1998; King \& Pankhurst, 2003) when natural water temperatures tend to be elevated.

Many aspects of the reproductive development of fish including spermatogenesis, oogenesis, spermiation and ovulation, are known to be significantly influenced by environmental temperature with effects of abnormally elevated temperatures being strongly detrimental (reviewed by Van Der Kraak \& Pankhurst, 1997). Exposure of salmonids to elevated temperature is known to inhibit FOM and ovulation in Arctic charr (Salvelinus alpinus L.) (Gillet, 1991), Atlantic salmon (Salmo salar L.) (Taranger \& Hansen, 1993; King \& Pankhurst, 2000) and rainbow trout (Oncorhynchus mykiss Walbaum) (Pankurst et al., 1996; Pankhurst and Thomas, 1998). In contrast, the effects of chronically-elevated environmental temperature on vitellogenesis are poorly understood. Exposure of Atlantic salmon post-smolts to $10^{\circ} \mathrm{C}$ increased the hepatic vitellogenic output relative to that observed at $3^{\circ} \mathrm{C}$ (Korsgaard et al., 1986). Similarly, 
MacKay \& Lazier (1993) reported a progressive increase in the rate and extent of Vtg production by rainbow trout held at 4,9 and $15^{\circ} \mathrm{C}$. Pankhurst et al. (1996) reported essentially unimpaired estrogen synthesis (and, by inference, vitellogenesis) in rainbow trout reared at temperatures as high as $21^{\circ} \mathrm{C}$ but Chmilevsky (2000) briefly described how gonadal development was arrested in the same species following exposure to 22$23^{\circ} \mathrm{C}$. Thus, it is unclear at which point the apparent stimulatory effect of elevated temperature on vitellogenesis becomes an inhibitory one. There is limited information on the effects of temperature change on vitellogenesis in non-salmonids. In the common wolffish (Anarhichas lupus L.), Tveiten \& Johnsen (2001) showed that exposure to elevated water temperatures $\left(12^{\circ} \mathrm{C}\right)$ during vitellogenesis delayed ovarian steroidogenesis, although effects on vitellogenesis, inferred from differences in egg size, were less clear (Tveiten \& Johnsen, 1999).

Preliminary studies on female Atlantic salmon showed impairment of ovarian steroidogenesis was also apparent during the late stages of vitellogenesis in fish held at elevated temperature (King \& Pankhurst, 2000). Plasma levels of both 17 $\beta$-estradiol $\left(\mathrm{E}_{2}\right)$ and its precursor testosterone $(\mathrm{T})$ were significantly reduced in fish held at $16^{\circ} \mathrm{C}$ relative to levels in fish held at 6 and $11^{\circ} \mathrm{C}$ (King \& Pankhurst, 2000). Because the primary function of $E_{2}$ is the stimulation of hepatic synthesis and ovarian sequestration of Vtg (Specker \& Sullivan, 1994), King \& Pankhurst (2000) concluded that the reduced viability observed in ova from fish maintained at $16^{\circ} \mathrm{C}$ might have resulted in part from impairment of vitellogenesis.

During a study of the natural reproductive development of female Atlantic salmon in Tasmania, King \& Pankhurst (2003) reported that oocyte size and plasma levels of $E_{2}, T$ and Vtg changed little during the hottest months of the austral summer (December - 
February), then showed rapid increases in March. This suggested that there was possibly temperature-related impairment of reproductive development during summer. Accordingly, the present study was conducted to assess the effect of elevated summer temperature on vitellogenesis and egg quality in Tasmanian female Atlantic salmon exposed from the early stages of vitellogenesis. Groups of female Atlantic salmon were maintained at temperatures of 14,18 and $22^{\circ} \mathrm{C}$ for 3 months from mid-summer onwards. At the end of the exposure period, temperatures were reduced to $8^{\circ} \mathrm{C}$ to facilitate FOM, ovulation and subsequent egg incubation. Blood samples were collected at regular intervals during the period of temperature manipulation, and plasma levels of $E_{2}, T$, cortisol and Vtg were measured to assess the relationship between endocrine status and Vtg production, and differences in reproductive development and gamete quality.

\section{MATERIALS AND METHODS}

\section{HUSBANDRY, TEMPERATURE AND PHOTOPERIOD REGIMES}

Ninety sexually maturing 2 year-old female Atlantic salmon (mean weight $4.6 \mathrm{~kg}$ ) were transported from a marine cage-farm operated by Aquatas Pty. Ltd., (Margate, Tasmania) to SALTAS Freshwater Operations (Wayatinah, Tasmania) in mid November 1998 and were maintained in a single circular $44 \mathrm{~m}^{3}$ outdoor tank supplied with river water $\left(\sim 151 . \mathrm{s}^{-1}\right)$ at natural temperature $\left(\sim 13-15^{\circ} \mathrm{C}\right.$ at time of transfer). Fish were fed to satiation on a commercial broodstock ration (Pivot Aquaculture Ltd., Cambridge, Tasmania). On 12 January 1999, fish were transferred from natural conditions (diurnal temperature range $15-20^{\circ} \mathrm{C}$ ) to 3 sets of 3 temperature-controlled 4 $\mathrm{m}^{3}$ Rathbun tanks (10 fish per tank) supplied with partially recirculated water $\left(\sim 1.5\right.$ 1.s ${ }^{-1}$ per tank) initially set at a temperature of $14^{\circ} \mathrm{C}$. Biological filtration and water 
exchanges of $50 \%$ per day were employed to prevent the accumulation of toxic metabolites. Oxygen saturation was maintained at $100-120 \%$ by the addition of gaseous oxygen via ceramic diffusers. Twenty-four hours after transfer, the temperature of one group of tanks was increased to $18^{\circ} \mathrm{C}$ and that of a second group to $22^{\circ} \mathrm{C}$ at a maximum rate of $1^{\circ} \mathrm{C}$.day ${ }^{-1}$. The third group was left at $14^{\circ} \mathrm{C}$. Following transfer to temperaturecontrolled conditions, fish were unfed and exposed to a simulated natural photoperiod $\left(42^{\circ} \mathrm{S}\right)$. In order to facilitate final oocyte maturation and ovulation, the water temperatures of all three tank groups were reduced after 13 April 1999, at a maximum rate of $2^{\circ} \mathrm{C}$.day ${ }^{-1}$, such that all three groups reached a temperature of $8^{\circ} \mathrm{C}$ on April 20 , the date by which fish under natural conditions would have been expected to have completed vitellogenesis (King \& Pankhurst, 2000, 2003).

\section{FISH SAMPLING AND HANDLING}

Twenty-four hours after the temperature-controlled groups had reached the correct holding temperatures of 14,18 or $22^{\circ} \mathrm{C}$, all fish from each of the three temperatures were anaesthetised (25p.p.m. Aqui-s, Crop \& Food, New Zealand) and tagged by placing visible implant tags (VI Tags, Northwest Marine Technology Inc, Shaw Island, WA) in the left adipose eyelid. Fish were also weighed to confirm that, as a result of random assignment, there were no significant differences in the mean weights of the 3 treatment groups (overall mean weight $5.2 \mathrm{~kg}$ ). Blood samples were taken from each fish by puncture of the duct of Cuvier (Lied et al., 1975) using heparinized (lithium heparin) syringes and $22 \mathrm{G}$ needles. After centrifugation, the resulting plasma was stored at $-20^{\circ} \mathrm{C}$ prior to analysis of steroid hormone and vitellogenin levels. Anaesthesia and blood sampling was repeated at 3 weekly intervals until mid April 1999. Ovulation checks of un-anaesthetised fish were commenced at the start of the recognised spawning season (late April) and continued at 3-4 day intervals until all surviving fish had 
ovulated (aside from 3 fish which escaped from one tank at $14^{\circ} \mathrm{C}$, there were no treatment-related differences in mortality which was $n=3,3$ and 2 at 14,18 and $22^{\circ} \mathrm{C}$ respectively).

\section{OVA FERTILISATION AND INCUBATION}

Fish that expressed ova in response to the gentle application of pressure to the abdomen were killed by a blow to the head, towelled dry and ova were expressed into a stainless steel sieve. In order to facilitate ova collection, a $2 \mathrm{~cm}$ cut was made at the genital papilla. Ova were transferred to a stainless steel bowl and fertilised using milt from 3-4 naturally spermiating males sourced from commercial broodstocks. Sperm pooling was used to avoid sperm quality problems as individual male milt quality was not checked. Ova and milt were gently mixed and $500 \mathrm{ml}$ water was added to ensure sperm activation. After 2 mins, ova were rinsed with clean water then left to waterharden for 60 mins. After water-hardening, sample batches (1000-1500) of ova from each female were removed and incubated at $8^{\circ} \mathrm{C}$ in mesh baskets $(4.0 \times 10.0 \times 12.0 \mathrm{~cm})$ placed in Heath vertical incubator trays (Marisource Inc., Tacoma, WA). Sub-samples of ova from each female were collected after water-hardening and fertilisation (\%) was determined on the basis of first cell division after 120 degree-hours, visualised by treatment with a clearing and fixing solution (5:4:6:85 $\mathrm{v} / \mathrm{v}$ formalin: acetic acid: glycerine: $1 \% \mathrm{NaCl}$ ) and the diameters of 10 fixed oocytes from each female were later measured ( $\pm 0.01 \mathrm{~mm}$ ) using digital vernier callipers. Eyed ova survival (\%) was observed directly after 250 degree-days of incubation. 


\section{PLASMA HORMONE AND VTG MEASUREMENT}

\section{Plasma Steroids}

Plasma levels of $E_{2}$, $T$ and cortisol were measured by radioimmunoassay following extraction with ethyl acetate using the reagents and protocols described by Pankhurst \& Carragher (1992). Extraction efficiency (mean recovery of ${ }^{3} \mathrm{H}$-labelled steroid from triplicates of a plasma pool) was $59.2-66.5$, 85.3-90.6\% and $94.3-100 \%$ for $\mathrm{E}_{2}, \mathrm{~T}$ and cortisol respectively and values for each steroid were adjusted accordingly. Interassay variability measured using aliquots of a pooled internal standard was (\%CV(n)) 12.4(10) and 10.8(10), 12.2(8) for $\mathrm{E}_{2}$, $\mathrm{T}$ and cortisol respectively.

\section{Plasma Vtg}

Plasma levels of Vtg were measured by Enzyme-linked Immunosorbent Assay (ELISA) using the reagents and protocol described by Watts et al. (2002). Interassay variability measured using aliquots of a pooled internal standard was (\%CV(n)) 11.5 (20).

\section{CHORION MORPHOLOGY}

At stripping, a sub-sample ( $\mathrm{n}=10-20)$ of unfertilised ova from each ovulated female was placed in Bouin's fixative and after 48h, fixed ova were transferred to $70 \%$ ethanol. Fixed ova stored in $70 \%$ ethanol were cut into quarters with a scalpel blade, and the chorion from one of the quarters was dehydrated in $90 \%$ ethanol for 30 mins, and then $100 \%$ ethanol for 30 mins, prior to critical point drying in a BAL-TEC CPD-030 critical point dryer. The dried samples were fixed to scanning electron microscope (SEM) stubs (5 samples per stub) with double-sided carbon tape to allow exposure of the outer surface of the chorion to the electron beam. The stubs were then coated with gold in a 
Union FL9496 Blazer splutter coater and chorion samples were observed at approximately 150x magnification using an Electro Scan Environmental SEM.

\section{STATISTICAL ANALYSIS}

Where appropriate, steroid, Vtg and egg quality data were analysed by one-way ANOVA and Tukey's HSD test using the SYSTAT 8.0 for Windows computer package. The same package was used to derive linear correlation coefficients between parameters and to construct contingency tables for the comparison of treatment-related differences in egg external morphology. Prior to analysis, proportion data were normalised by arcsin transformation.

\section{RESULTS}

Ovulations in fish from all three temperature regimes commenced simultaneously on 18 May (Fig. 1). The 14 and $22^{\circ} \mathrm{C}$ treatment groups completed ovulation on 6 June, whereas fish from the $18^{\circ} \mathrm{C}$ treatment did not complete ovulation for a further 8 days. A level of $80 \%$ ovulation was first exceeded by fish from the $22^{\circ} \mathrm{C}$ treatment on 24 May, whereas similar progress was only achieved by the 14 and $18^{\circ} \mathrm{C}$ treatment groups after a further 7 and 17 days respectively.

The mean diameters of ova from fish from the 14 and $18^{\circ} \mathrm{C}$ temperature treatments were not significantly different ( $5.7 \mathrm{~mm}$, Table I). However, ova from fish which had been held at $22^{\circ} \mathrm{C}$ were significantly smaller $(\sim 5.4 \mathrm{~mm})$ than those from fish held at 14 and $18^{\circ} \mathrm{C}$ (Table I). Mean fertility exceeded $85 \%$ in ova from fish which had been held at 14 and $18^{\circ} \mathrm{C}$ but was significantly lower (below 70\%) in ova from fish maintained at $22^{\circ} \mathrm{C}$ (Table I). Similarly, mean eyed-egg survival was greater than $80 \%$ in ova from fish held at 14 or $18^{\circ} \mathrm{C}$, whereas ova from fish held at $22^{\circ} \mathrm{C}$ displayed a significantly lower mean survival of only 42\% (Table I). 
Plasma $\mathrm{E}_{2}$ levels in fish held at $22^{\circ} \mathrm{C}$ were significantly lower than in fish held at $14^{\circ} \mathrm{C}$ at four out of five sample points (Fig. 2), and significantly lower than at $18^{\circ} \mathrm{C}$ at the first two sample points (Fig. 2). $\mathrm{E}_{2}$ levels at $18^{\circ} \mathrm{C}$ were also significantly lower than those at $14^{\circ} \mathrm{C}$ at the final sample point (Fig. 2). In contrast, plasma $\mathrm{T}$ levels in fish held at $22^{\circ} \mathrm{C}$ tended to be higher than those in fish held at either 14 or $18^{\circ} \mathrm{C}$ at three out of five sample points (Fig. 3). At the final sample, plasma $\mathrm{T}$ levels were significantly lower in fish held at 18 and $22^{\circ} \mathrm{C}$ than in fish maintained at $14^{\circ} \mathrm{C}$ (Fig. 3).

Plasma cortisol levels were initially high in all treatments and declined as sampling progressed (Fig. 3). Cortisol levels in fish held at $22^{\circ} \mathrm{C}$ were higher than those in fish held at $14^{\circ} \mathrm{C}$ for the first four samples, and values in fish held at $18^{\circ} \mathrm{C}$ were also higher than those in fish held at $14^{\circ} \mathrm{C}$ in four out of five samples (Fig. 3). Plasma Vtg levels were significantly higher at $14^{\circ} \mathrm{C}$ than $22^{\circ} \mathrm{C}$ for the first three samples, after which there was a marked increase in plasma Vtg levels in fish held at $22^{\circ} \mathrm{C}$ (Fig. 4). Plasma Vtg levels at $18^{\circ} \mathrm{C}$ were also lower than those at $14^{\circ} \mathrm{C}$ in three out of five samples.

Comparison of $E_{2}$, Vtg and cortisol data revealed that, plasma Vtg levels displayed a weak but significant positive correlation with plasma $E_{2}$ levels at the first $(R=0.42$, Bartlett $\chi^{2}$-Statistic $=16.7$, d.f. $\left.=1, \mathrm{P}<0.001\right)$ and second samples $(\mathrm{R}=0.33$, Bartlett $\chi^{2}$-Statistic $=8.8$, d.f. $\left.=1, \mathrm{P}<0.01\right)$. Similarly, plasma Vtg levels displayed a weak but significant negative correlation with plasma cortisol levels at the first $(\mathrm{R}=-0.48$, Bartlett $\chi^{2}$-Statistic $=19.8$, d.f. $\left.=1, \mathrm{P}<0.001\right)$ and second samples $(\mathrm{R}=-0.44$, Bartlett $\chi^{2}$-Statistic $=16.1$, d.f. $\left.=1, \mathrm{P}<0.001\right)$ but there was no significant relationship between plasma $E_{2}$ and cortisol levels at any sample time.

Examination of chorion morphology revealed a number of differing egg surface characteristics. The majority of samples exhibited a chorion surface where the pore 
channel plugs were clearly visible (Fig. 4a and b). The open micropyle of the ovum was also visible in a number of samples (Fig. 4c). However, in addition to the normal features above, holes were observed in the chorion of many samples (Fig. 4d). These holes appeared to have originated from blister-like eruptions on the surface of the chorion resulting in raised craters of 2-10 $\mu \mathrm{m}$ in diameter (Fig. 4d). Closer examination revealed that the holes were irregular in diameter and that they were partially obstructed by fibrous material (Fig. 4e).

Among fish maintained at $14^{\circ} \mathrm{C}, 27.3 \%$ of females produced ova that contained abnormal holes (Table II) and the mean incidence of holes in those egg batches was $32.6 \%$. At $18^{\circ} \mathrm{C}, 60.9 \%$ of females produced ova with holes and the mean incidence of holes was $31.9 \%$ (Table II), while at $22^{\circ} \mathrm{C}$, $38.5 \%$ of females produced ova with holes at a mean incidence of $38.4 \%$ (Table II). The proportion of females which produced damaged ova was significantly higher at $18^{\circ} \mathrm{C}$ than at $14^{\circ} \mathrm{C}$, whereas, the proportion of females at $22^{\circ} \mathrm{C}$ which produced damaged ova did not differ significantly from that at either 14 or $18^{\circ} \mathrm{C}$ (Table II). Among damaged batches of ova there were no significant differences in the mean incidence of holes (Table II).

There were weak but significant negative correlations between percent survival of ova to the eyed stage and incidence of holes for ova from fish maintained at $14^{\circ} \mathrm{C}(\mathrm{R}=$ 0.63, Bartlett $\chi^{2}$-Statistic $=9.8$, d.f. $\left.=1, \mathrm{P}<0.01\right)$ and at $18^{\circ} \mathrm{C}\left(\mathrm{R}=-0.47\right.$, Bartlett $\chi^{2}$ Statistic $=5.2$, d.f. $=1, \mathrm{P}<0.05$ ) whereas, for ova from fish held at $22^{\circ} \mathrm{C}$, there was no significant correlation between the incidence of chorion damage and the survival of ova. 


\section{DISCUSSION}

Exposure to elevated temperature during vitellogenesis was associated with significant reductions of both the fertility and the survival of ova from female Atlantic salmon. Mean fertility of ova from fish held at $22^{\circ} \mathrm{C}$ was less than $70 \%$ and subsequent survival to the eyed stage was only 40\% whereas, values for both parameters exceeded $80 \%$ for fish held at 14 and $18^{\circ} \mathrm{C}$. While there have been no reports of directly comparable studies in other salmonids, Chmilevsky (2000) observed arrested gonadal development in rainbow trout held at $22-23^{\circ} \mathrm{C}$. In addition, the present results are broadly consistent with those reported by Pankhurst et al. (1996) in rainbow trout, where maintenance at 18 and $21^{\circ} \mathrm{C}$ for the 3 months prior to ovulation was associated with failure to produce viable ova. Similarly, in a study of coho salmon (Oncorhynchus kisutch Walbaum) from the Great Lakes of North America, Flett et al. (1996) reported highly variable fertility (0 to $>80 \%$ ) and low survival to hatch $(42 \%)$ in ova from females which had been exposed to elevated temperatures during the 5 months preceding spawning. Furthermore, in an examination of reproductive performance in the common wolffish which more closely resembled the design of the present study (albeit at a lower range of temperatures), Tveiten \& Johnsen (1999) observed a trend of declining egg survival in association with increasing holding temperature during vitellogenesis.

Bromage et al. $(1992,1993)$ suggested that reproductive phasing in salmonids is almost totally dependent on photoperiod, whereas temperature is typically understood to have a permissive role, inhibiting maturation at its upper and lower extremes. However, the present observation of accelerated and more synchronous ovulation following temperature reduction in fish previously held at $22^{\circ} \mathrm{C}$ also indicates the involvement of temperature in cueing maturation in female Atlantic salmon, and suggests that the 
magnitude and/or rate of temperature reduction may assist in entraining an endogenous reproductive rhythm in a manner similar to that reported for changes in photoperiod (eg, Porter et al., 2000; Randall et al., 2000). Taranger et al. (2000) also reported that exposure to reduced water temperatures (approximately $5^{\circ} \mathrm{C}$ below natural) both synchronised and advanced ovulation in Atlantic salmon. Duncan et al. (2000) reported that the timing of ovulation in female Atlantic salmon was less photoperiod-labile than in rainbow trout and concluded that a temperature-sensitive mechanism was partially responsible for the control of maturation in female salmon.

In general, the patterns of $\mathrm{E}_{2}$ and $\mathrm{T}$ production observed during the present study agree with those presented by King \& Pankhurst (2003). In mid January, both steroids were recorded at levels of $\sim 2-3$ ng. $\mathrm{ml}^{-1}$ and levels increased approximately 7 to 10 -fold as sampling progressed. King \& Pankhurst (2003) reported that plasma $E_{2}$ and $T$ in unmanipulated female Atlantic salmon increased from $~ 2-5$ ng. $\mathrm{ml}^{-1}$ to $20-25$ ng. $\mathrm{ml}^{-1}$ over a similar timeframe. Furthermore, the generally lower $\mathrm{E}_{2}$ production in fish held at $22^{\circ} \mathrm{C}$ is consistent with the observations of King \& Pankhurst (2000) of an apparent impairment of ovarian steroidogenesis during the latter stages of vitellogenesis in salmon maintained at $16^{\circ} \mathrm{C}$. This supports the contention that exposure to elevated temperatures may influence vitellogenic as well as maturational processes in Atlantic salmon (King \& Pankhurst, 2000) but contrasts with the conclusions of Pankhurst et al. (1996) and Pankhurst \& Thomas (1998) who reported inconsistent effects of elevated temperatures on ovarian steroidogenesis during vitellogenesis in female rainbow trout.

The present reduction in $\mathrm{E}_{2}$ and elevation in $\mathrm{T}$ observed during the earlier stages of sampling (January to March) in fish held at $22^{\circ} \mathrm{C}$ is suggestive of impaired $\mathrm{E}_{2}$ synthesis. As conversion of $\mathrm{T}$ to $\mathrm{E}_{2}$ is dependent on the activity of the aromatase cytochrome $\mathrm{P} 450$ 
(P450 arom) enzyme system (reviewed by Nagahama et al., 1993), the present observations suggest that the impairment of ovarian steroidogenesis during the early stages of sampling was largely restricted to inhibition of $\mathrm{P} 450_{\text {arom }}$ activity. In contrast, the observation of significant reductions in both $\mathrm{E}_{2}$ and $\mathrm{T}$ in fish from the 18 and $22^{\circ} \mathrm{C}$ treatments at the final sample point indicates that impairment of ovarian steroidogenesis involved enzymes higher in the synthetic pathway at that stage.

At the commencement of sampling, Vtg levels in fish held at 14 and $18^{\circ} \mathrm{C}$ were consistent with those reported in rainbow trout at a similar stage of development $(\sim 10$ 15 mg.ml ${ }^{-1}$, Tyler et al., 1990). However, the absence of a subsequent increase in plasma Vtg, concomitant with the observed increases in plasma $\mathrm{E}_{2}$ and $\mathrm{T}$, is unexpected and the cause unclear. In contrast, in spite of a later, rapid elevation, initial Vtg levels at $22^{\circ} \mathrm{C}$ were low $\left(\sim 5 \mathrm{mg}^{-1}\right.$ ), implying impairment of vitellogenesis at $22^{\circ} \mathrm{C}$ during January and February. The majority of the salmonid literature tends to indicate that increased temperature actually favours rather than impairs Vtg production. For example, Olin \& Von Der Decken (1989) observed an increase in serum Vtg from 10 mg.ml ${ }^{-1}$ to $\sim 28 \mathrm{mg} \cdot \mathrm{ml}^{-1}$ in Atlantic salmon smolts in association with an increase in temperature from 8 to $16^{\circ} \mathrm{C}$ and calculated a $\mathrm{Q}_{10}$ temperature coefficient for Vtg production of 3.71. Korsgaard et al. (1986), using serum levels of alkali-labile phosphorous and calcium as indicators of circulating Vtg, observed a failure to produce Vtg following $\mathrm{E}_{2}$ treatment in Atlantic salmon post-smolts held at $3^{\circ} \mathrm{C}$. In contrast, $\mathrm{E}_{2}$-treated fish held at $10^{\circ} \mathrm{C}$ or transferred to $10^{\circ} \mathrm{C}$ from $3^{\circ} \mathrm{C}$ exhibited increased serum levels of alkali-labile phosphorous $\left(\sim 12 \mu \mathrm{g} \cdot \mathrm{ml}^{-1}\right)$ and calcium $(\sim 4-5 \mathrm{mM})$ relative to controls $\left(\sim 0.7 \mu \mathrm{g} \cdot \mathrm{ml}^{-1}\right.$ and $\sim 2.8 \mathrm{mM}$ respectively). Similarly, rainbow trout held at $15^{\circ} \mathrm{C}$ exhibited measurable Vtg production within $24 \mathrm{~h}$ of $\mathrm{E}_{2}$ injection, with plasma Vtg peaking at $\sim 70 \mathrm{mg} \cdot \mathrm{ml}^{-1}$ within 10 days (MacKay and Lazier, 1993) whereas, in fish held at $9^{\circ} \mathrm{C}$ plasma Vtg 
appeared later $(\sim 72 \mathrm{~h})$ and reached a level of only $8.9 \mathrm{mg}^{-1} \mathrm{ml}^{-1}$ after 10 days. Furthermore, production of Vtg mRNA was detected within $8 \mathrm{~h}$ in fish held at $15^{\circ} \mathrm{C}$ but took $\sim 24$ and $\sim 48 \mathrm{~h}$ at 9 and $4{ }^{\circ} \mathrm{C}$ respectively. As all the above studies were conducted at temperatures near or below the lowest temperature used in the present study this implies that increasing temperature is stimulatory in terms of Vtg production up to a certain point, beyond which it becomes inhibitory. In Tasmanian populations of Atlantic salmon this effect becomes apparent at temperatures above $18^{\circ} \mathrm{C}$.

Almost all of the contents which determine the quality of a fish egg must be incorporated into the oocyte during ovarian growth (reviewed by Brooks et al., 1997; Tyler et al., 2000). Accordingly, since uptake of Vtg can account for more than $90 \%$ of final oocyte volume in salmonids (reviewed by Tyler, 1991; Tyler et al., 2000) the significance of impaired vitellogenic growth for gamete quality and subsequent embryo viability is likely to be high. In rainbow trout, for example, treatments which resulted in a $\sim 46 \%$ reduction in plasma Vtg levels also resulted in reductions in egg weight and egg volume of $\sim 13 \%$ and $\sim 17 \%$ respectively, and were associated with reduced survival of eggs to the eyed stage of development ( 54\% c.f. 96\% in controls) (Campbell et al., 1994). During the present study, the size, fertility and survival of ova from fish held at $22^{\circ} \mathrm{C}$ were also significantly reduced. In addition, significantly reduced levels of Vtg were observed at each of the first three sample points in fish held at $22^{\circ} \mathrm{C}$ relative to those at $14^{\circ} \mathrm{C}$. The observation of weak but statistically significant correlations between plasma Vtg levels and plasma $\mathrm{E}_{2}$ levels at the first and second samples are consistent with the known role of $\mathrm{E}_{2}$ in stimulating vitellogenesis (reviewed by Mommsen \& Walsh, 1988; Tyler, 1991; Specker \& Sullivan, 1994) and suggest that the reduced performance of ova from fish held at $22^{\circ} \mathrm{C}$ was associated with the significant reductions in $\mathrm{E}_{2}$ observed during January and February. 
Reductions in circulating $\mathrm{E}_{2}$ and Vtg in fish held at high temperatures may represent a stress effect. Carragher et al. (1989) reported a depression of plasma $\mathrm{E}_{2}$ and Vtg levels in female rainbow trout following artificial elevation of plasma cortisol levels. In later experiments, plasma Vtg levels in rainbow trout were halved following 2 weeks of confinement stress, while implantation of female brown trout (Salmo trutta L.) with a slow-release cortisol pellet resulted in reduced plasma $E_{2}\left(2\right.$ c.f. 7 ng.ml $\left.{ }^{-1}\right)$ and Vtg (6 c.f. 24 mg.ml ${ }^{-1}$ )(Pottinger et al., 1991). During the present study, plasma cortisol levels were relatively high at all temperatures $\left(\sim\right.$ 30-100 ng.ml $\left.{ }^{-1}\right)$ and no doubt primarily reflected an acute response to the stress of sampling. Nonetheless, plasma cortisol levels were generally higher at elevated temperatures and there was a weak but significant negative correlation between plasma cortisol and Vtg levels in early samples, suggesting a temperature treatment-related stress effect on vitellogenesis. However, there was no significant relationship between plasma cortisol and plasma $E_{2}$. This is not unexpected since the role of cortisol as a direct mediator of stress on reproduction and, in particular, ovarian steroidogenesis has been difficult to demonstrate unequivocally (eg. Pankhurst et al., 1995; Pankhurst, 1998, Leatherland, 1999) and it has only recently become apparent that cortisol-mediated inhibition of reproduction may result from effects at the level of GtH signal-transduction (Pankhurst \& Van Der Kraak, 2000).

$E_{2}$ is also responsible for stimulating hepatic synthesis of egg-shell proteins in teleost fish (zonagenesis, Hyllner \& Haux, 1995). In Atlantic salmon, plasma levels of egg shell or zona radiata (ZR) proteins closely correlate with plasma levels of $E_{2}$ throughout the annual reproductive cycle (Oppen-Berntsen et al., 1994), and in vitro ZR protein synthesis has been shown to be more responsive than Vtg synthesis to $\mathrm{E}_{2}$ (Celius \& Walther, 1998). This suggests that the temperature-related differences in $E_{2}$ and Vtg observed during the present study might also be reflected in the reduced production of 
ZR proteins. The ZR assists in protecting the developing embryo against mechanical damage, desiccation and fluctuating environmental conditions while also exhibiting bactericidal and fungicidal properties (reviewed by Hyllner \& Haux, 1995). In consequence, impairment of $\mathrm{ZR}$ protein synthesis or $\mathrm{ZR}$ assembly is likely to be reflected in lowered egg survival. In the present study, weak but significant correlations were observed between survival and the incidence of egg shell damage (at least in ova from fish held at 14 and $18^{\circ} \mathrm{C}$ ) and the fact that the damage was already present at the point of release from the female genital pore confirms the maternal origin of the phenomenon. However, the possible role of holding temperature as a causal factor is less clear. Here, the limitations of the ova sampling should be acknowledged. Only 1020 ova were sampled from each female and only one quarter of each ovum was examined, while the numbers and sizes of holes were not evaluated and only their presence or absence recorded. Nonetheless, the incidence of shell damage was lowest and embryo survival highest in ova from fish held at $14^{\circ} \mathrm{C}$.

In summary, maintenance of female Atlantic salmon at a water temperature of $22^{\circ} \mathrm{C}$ during vitellogenesis was associated with a general reduction in plasma $\mathrm{E}_{2}$ levels and an early reduction in plasma Vtg levels relative to those observed in fish held at 14 and $18^{\circ} \mathrm{C}$. A resultant reduction in maternal investment was confirmed by a significant reduction in oocyte diameter in ova from fish held at $22^{\circ} \mathrm{C}$ while a concomitant increase in the incidence of previously undescribed chorion damage indicated possible impairment of zonagenesis as well as vitellogenesis. Elevated temperature may have acted directly at the level of the reproductive endocrine cascade or indirectly via the stress axis. The net effect was a significant reduction in the viability of ova from fish exposed to high temperatures during vitellogenesis. 


\section{ACKNOWLEDGEMENTS}

We are grateful to the staff of Salmon Enterprises of Tasmania Pty. Ltd. (Saltas) for expert assistance with fish maintenance and sample collection. Thanks are also due to Mr. M. Willis for his assistance with SEM sample preparation and electron micrograph capture. This work was supported by Saltas, the Australian Cooperative Research Centre for Aquaculture and an Australian Research Council infrastructure grant.

\section{REFERENCES}

Billard, R. (1985). Environmental factors in salmonid culture and the control of reproduction. In Salmonid Reproduction International Symposium, (Iwamoto, R.N. \& Sower, S. eds.), pp. 70-87. Seattle, WA: Washington Sea Grant Communications.

Bromage, N.R. \& Cumaranatunga, R. (1988). Egg production in the rainbow trout. In Recent Advances in Aquaculture, Vol. III (Muir, J.F. \& Roberts, R.J., eds.), pp. 63-138. London: Croom Helm.

Bromage, N.R., Jones, J., Randall, C., Thrush, M., Davies, B., Springate, J., Duston, J. \& Barker, G. (1992). Broodstock management, fecundity, egg quality and the timing of egg production in the rainbow trout (Oncorhynchus mykiss). Aquaculture 100, 141-166.

Bromage, N.R., Randall, C., Duston, J., Thrush, M. \& Jones, J. (1993). Environmental control of reproduction in salmonids. In Recent Advances in Aquaculture, Vol. IV (Muir, J.F. \& Roberts, R.J., eds.), pp. 55-65. Oxford: Blackwell Scientific Publications.

Brooks, S., Tyler C.R. \& Sumpter, J.P. (1997). Egg quality in fish: what makes a good egg? Reviews in Fish Biology and Fisheries 7, 387-416.

Campbell, P.M., Pottinger, T.G \& Sumpter, J.P. (1994). Preliminary evidence that chronic confinement stress reduces the quality of gametes produced by brown and rainbow trout. Aquaculture 120, 151-169.

Carragher, J.F., Sumpter, J.P., Pottinger, T.G. \& Pickering, A.D. (1989). The deleterious effects of cortisol implantation on reproductive function in two species 
of trout, Salmo trutta L. and Salmo gairdneri Richardson. General and Comparative Endocrinology 76, 310-321.

Celius, T. \& Walther, B.T. (1998). Oogenesis in Atlantic salmon (Salmo salar L.) occurs by zonagenesis preceding vitellogenesis in vivo and in vitro. Journal of Endocrinology 158, 259-266.

Chmilevsky, D.A. (2000). Effects of extreme temperature on oogenesis in tilapia and rainbow trout. In Proceedings of the 6th International Symposium on the Reproductive Physiology of Fish, (Norberg, B., Kjesbu, O.S., Taranger, G.L. Andersson, E. \& Stefansson, S.O., eds.) p 316. Bergen: John Grieg A/S.

Duncan, N.J., Selkirk, C., Porter, M., Hunter, D., Magwood, S. \& Bromage, N. (2000). The effect of altered photoperiods on maturation of male and female Atlantic salmon (Salmo salar). In Proceedings of the 6th International Symposium on the Reproductive Physiology of Fish, (Norberg, B., Kjesbu, O.S., Taranger, G.L. Andersson, E. \& Stefansson, S.O., eds.) p. 344. Bergen: John Grieg A/S.

Estay, F., Neira, R., Diaz, N.F., Valladares, L. \& Torres, A. (1998). Gametogenesis and sex steroid profiles in cultured coho salmon (Oncorhynchus kisutch, Walbaum). Journal of Experimental Zoology 280, 429-438.

Flett, P.A., Munkittrick, K.R., Van Der Kraak, G \& Leatherland, J.F. (1996). Overripening as the cause of low survival to hatch in Lake Erie coho salmon (Oncorhynchus kisutch) embryos. Canadian Journal of Zoology 74, 851-857.

Gillet, C. (1991). Egg production in an Arctic charr (Salvelinus alpinus L.) brood stock: Effects of temperature on the timing of spawning and the quality of eggs. Aquatic Living Resources 4, 109-116.

Hyllner, S.J. \& Haux, C. (1995). Vitelline envelope proteins in teleost fish. In Reproductive Physiology of Fish 1995, (Goetz, F.W. \& Thomas, P., eds.), pp. 331-335. Austin: Fish Symposium 95.

King, H.R. \& Pankhurst, N.W. (2000). Ovulation of Tasmanian Atlantic salmon maintained at elevated temperatures: implications of climate change for sustainable industry development. In Proceedings of the 6th International Symposium on the Reproductive Physiology of Fish, (Norberg, B., Kjesbu, O.S., Taranger, G.L. Andersson, E. \& Stefansson, S.O., eds.) pp. 396-398. Bergen: John Grieg A/S. 
King, H.R. \& Pankhurst, N.W. (2003). Ovarian growth and plasma sex steroid and vitellogenin profiles during vitellogenesis in Tasmanian female Atlantic salmon (Salmo salar). Aquaculture in press.

Korsgaard, B., Mommsen, T.P. \& Saunders, R.L. (1986). The effect of temperature on the vitellogenic response in Atlantic salmon post-smolts (Salmo salar). General and Comparative Endocrinology 62, 191-201.

Leatherland, J.F. (1999). Stress, cortisol and reproductive dysfunction in salmonids: fact or fallacy? Bulletin if the European Association of Fish Pathologists 19, 254-257.

Lied, E., Gjerde, J. \& Braekkan, O.R. (1975). A simple and rapid technique for repeated blood sampling in rainbow trout (Salmo gairdneri). Journal of the Fisheries Research Board of Canada 32, 699-701.

MacKay, M.E. \& Lazier, C.B. (1993). Estrogen responsiveness of vitellogenin gene expression in rainbow trout (Oncorhynchus mykiss) kept at different temperatures. General and Comparative Endocrinology 89, 255-266.

Mommsen, T.P. \& Walsh, P.J. (1988). Vitellogenesis and oocyte assembly. In Fish Physiology, Vol. XIA, (Hoar, W.S. \& Randall, D.J., eds.), pp. 247-406. New York: Academic Press.

Nagahama, Y., Yoshikuni, M., Yamashita, M., Sakai N. \& Tanaka, M. (1993). Molecular endocrinology of oocyte growth and maturation in fish. Fish Physiology and Biochemistry 11, 3-14.

Olin, T. \& Von Der Decken, A. (1989). Vitellogenin synthesis in Atlantic salmon (Salmo salar) at different acclimation temperatures. Aquaculture 79, 397-402.

Oppen-Berntsen, D.O., Olsen, S.O., Rong, C.J., Taranger, G.L., Swanson, P. \& Walther, B.T. (1994). Plasma levels of eggshell zr-proteins, estradiol-17 $\beta$, and gonadotropins during an annual reproductive cycle of Atlantic salmon (Salmo salar). Journal of Experimental Zoology 268, 59-70.

Pankhurst, N.W. (1998). Further evidence of the equivocal effects of cortisol on in vitro steroidogenesis by ovarian follicles of rainbow trout Oncorhynchus mykiss. Fish Physiology and Biochemistry 19, 315-323.

Pankhurst, N.W. \& Carragher, J.F. (1992). Oocyte maturation and changes in plasma steroid levels in snapper Pagrus (= Chrysophrys) auratus (Sparidae) following treatment with human chorionic gonadotropin. Aquaculture 101, 337-347. 
Pankhurst, N.W. \& Thomas, P.M. (1998). Maintenance at elevated temperature delays the steroidogenic and ovulatory responsiveness of rainbow trout Oncorhynchus mykiss to luteinizing hormone releasing hormone analogue. Aquaculture 166, 163-177.

Pankhurst, N.W. \& Van Der Kraak, G. (2000). Evidence that acute stress inhibits ovarian steroidogenesis in rainbow trout in vivo through the action of cortisol. General and Comparative Endocrinology 117, 225-237.

Pankhurst, N.W., Van Der Kraak, G. \& Peter, R.E. (1995). A reassessment of the inhibitory effects of cortisol on ovarian steroidogenesis. In Reproductive Physiology of Fish 1995, (Goetz, F.W. \& Thomas, P., eds.), p. 195. Austin: Fish Symposium 95.

Pankhurst, N.W., Purser, G.J., Van Der Kraak, G., Thomas, P.M. \& Forteath, G.N.R. (1996). Effect of holding temperature on ovulation, egg fertility, plasma levels of reproductive hormones and in vitro ovarian steroidogenesis in the rainbow trout Oncorhynchus mykiss. Aquaculture 146, 277-290.

Porter, M.J.R., Duncan, N.J., Roed, A.J., Oppedal, F., Taranger, G.L. \& Bromage, N.R. (2000). Differential effects of light intensity on growth, maturation and plasma melatonin in Atlantic salmon and its importance in aquaculture. In Proceedings of the 6th International Symposium on the Reproductive Physiology of Fish, (Norberg, B., Kjesbu, O.S., Taranger, G.L. Andersson, E. \& Stefansson, S.O., eds.) pp. 321-324. Bergen: John Grieg A/S.

Pottinger, T.G., Campbell, P.M. \& Sumpter, J.P. (1991). Stress-induced disruption of the salmonid liver-gonad axis. In Reproductive Physiology of Fish, (Scott, A.P., Sumpter, J.P., Kime, D.E. \& Rolfe, M.S., eds.), pp. 114-116. Sheffield: FishSymp91.

Randall, C.F., Bromage, N.R., Porter, M.J.R., Gardener, J. \& Auchinachie, N.A. (2000). Circannual rhythms of reproduction in rainbow trout. In Proceedings of the 6th International Symposium on the Reproductive Physiology of Fish, (Norberg, B., Kjesbu, O.S., Taranger, G.L. Andersson, E. \& Stefansson, S.O., eds.) pp. 325327. Bergen: John Grieg A/S. 
Scott, A.P. (1990). Salmonids. In Reproductive Seasonality in Teleosts: Environmental Influences, (Munro, A.D., Scott, A.P. \& Lam, T.J., eds.), pp. 33-51. Boca Raton, Florida: CRC Press.

Specker, J.L. \& Sullivan, C.V. (1994). Vitellogenesis in fishes: status and perspectives. In Perspectives in Comparative Endocrinology (Davey, K.G., Peter, R.E. \& Tobe, S.S., eds.), pp. 304-315. Ottawa: National Research Council of Canada.

Taranger, G.L. \& Hansen, T. (1993). Ovulation and egg survival following exposure of Atlantic salmon, Salmo salar L., broodstock to different water temperatures. Aquaculture and Fisheries Management 24, 151-156.

Taranger, G.L., Stefansson, S.O., Oppedal, F., Andersson, E., Hansen, T. \& Norberg, B., 2000. Photoperiod and temperature affect spawning time in Atlantic salmon (Salmo salar L.). In Proceedings of the 6th International Symposium on the Reproductive Physiology of Fish, (Norberg, B., Kjesbu, O.S., Taranger, G.L. Andersson, E. \& Stefansson, S.O., eds.) p. 345. Bergen: John Grieg A/S.

Tveiten, H. \& Johnsen, H. K. (1999). Temperature experienced during vitellogenesis influences ovarian maturation and the timing of ovulation in common wolffish. Journal of Fish Biology 55, 809-819.

Tveiten, H. \& Johnsen, H. K. (2001). Thermal influences on temporal changes in plasma testosterone and oestradiol-17 $\beta$ concentrations during gonadal recrudescence in female common wolffish. Journal of Fish Biology 59, 175-178.

Tyler, C.R. (1991). Vitellogenesis in salmonids. In Reproductive Physiology of Fish, (Scott, A.P., Sumpter, J.P., Kime, D.E. \& Rolfe, M.S., eds.), pp.295-299.. Sheffield: FishSymp91.

Tyler, C.R., Sumpter, J.P. \& Witthames, P.R. (1990). The dynamics of oocyte growth during vitellogenesis in the rainbow trout (Oncorhynchus mykiss). Biology of Reproduction 43, 202-209.

Tyler, C.R., Santos, E.M. \& Prat, F. (2000). Unscrambling the egg - cellular, biochemical, molecular and endocrine advances in oogenesis. In Proceedings of the 6th International Symposium on the Reproductive Physiology of Fish, (Norberg, B., Kjesbu, O.S., Taranger, G.L. Andersson, E. \& Stefansson, S.O., eds.) pp. 273-280. Bergen: John Grieg A/S. 
Van Der Kraak, G. \& Pankhurst, N.W. (1997). Temperature effects on the reproductive performance of fish. In Global Warming: Implications for Freshwater and Marine Fish, (Wood, C.M. \& McDonald, D.G., eds.), Society for Experimental Biology Seminar Series 61, Cambridge University Press, Cambridge, pp 159-176.

Watts, M., Pankhurst, N.W., Hobby, A. \& Sun, B. (2002). Vitellogenin isolation, purification and antigenic cross-reactivity in three teleost species. Comparative Biochemistry and Physiology in press. 
Table I Mean ( \pm SEM) diameter (mm), mean fertility (\%) and mean survival to the eyed stage (\%) of ova from female Atlantic salmon maintained at 14,18 , or $22^{\circ} \mathrm{C}(\mathrm{C} . \mathrm{L} .=$ confidence limit). Figures with the same superscript are not significantly different $(\mathrm{P}>0.05)$.

\begin{tabular}{lccc}
\hline & \multicolumn{3}{c}{ Temperature Regime ( $\left.{ }^{\circ} \mathbf{C}\right)$} \\
& $\mathbf{1 4}$ & $\mathbf{1 8}$ & $\mathbf{2 2}$ \\
\hline Mean Egg Diameter (mm) & $5.760^{\mathrm{a}}$ & $5.668^{\mathrm{a}}$ & $5.396^{\mathrm{b}}$ \\
SEM & \pm 0.056 & \pm 0.032 & \pm 0.058 \\
Mean Egg Fertility (\%) & $93.4^{\mathrm{a}}$ & $86.5^{\mathrm{a}}$ & $69.4^{\mathrm{b}}$ \\
Upper 95\% C.L. & 100.00 & 97.11 & 99.95 \\
Lower 95\% C.L. & 75.38 & 36.40 & 16.69 \\
Mean Egg Survival (\%) & $85.6^{\mathrm{a}}$ & $84.5^{\mathrm{a}}$ & $41.9^{\mathrm{b}}$ \\
Upper 95\% C.L. & 95.74 & 88.90 & 98.30 \\
Lower 95\% C.L. & 30.43 & 16.76 & 0.11 \\
\hline
\end{tabular}


Table II Proportion of egg batches from female Atlantic salmon maintained at 14, 18 , or $22^{\circ} \mathrm{C}$ which contained damaged ova and mean ( \pm SEM) incidence of damage in those egg batches. Egg batch refers to the ova from a single female. Figures with the same superscript are not significantly different (P > 0.05).

\begin{tabular}{lccc}
\hline & \multicolumn{3}{c}{ Temperature Regime $\left({ }^{\circ} \mathbf{C}\right)$} \\
& $\mathbf{1 4}$ & $\mathbf{1 8}$ & $\mathbf{2 2}$ \\
\hline $\begin{array}{l}\text { Proportion of Damaged } \\
\text { Egg Batches (\%) }\end{array}$ & $27.3^{\mathrm{a}}$ & $60.9^{\mathrm{b}}$ & $38.5^{\mathrm{ab}}$ \\
& & & \\
Mean Incidence of & $32.6^{\mathrm{a}}$ & $31.9^{\mathrm{a}}$ & $38.4^{\mathrm{a}}$ \\
Damaged Eggs (\%) & \pm 5.1 & \pm 3.0 & \pm 7.8 \\
\hline
\end{tabular}




\section{FIGURE LEGENDS}

FIG. 1. Cumulative percent ovulation in female Atlantic salmon maintained at $14^{\circ} \mathrm{C}$ ()), $18^{\circ} \mathrm{C}(\&)$, or $22^{\circ} \mathrm{C}(')$.

FIG. 2. Mean ( \pm S.E.M.) plasma levels $\left(n g . \mathrm{ml}^{-1}\right)$ of $17 \beta$-estradiol $\left(\mathrm{E}_{2}\right)$ and testosterone (T) in female Atlantic salmon maintained at $14^{\circ} \mathrm{C} \mathrm{()),} 18^{\circ} \mathrm{C}(\&)$, or $22^{\circ} \mathrm{C}(')$. At each sample time data points with the same superscript are not significantly different $(\mathrm{P}>0.05), \mathrm{n}=23-29$.

FIG. 3. Mean ( \pm S.E.M.) plasma levels of cortisol (ng. $\mathrm{ml}^{-1}$ ) and vitellogenin (Vtg, mg.ml ${ }^{-1}$ ) in female Atlantic salmon maintained at $\left.14^{\circ} \mathrm{C}()\right), 18^{\circ} \mathrm{C}(\&)$, or $22^{\circ} \mathrm{C}$ ('). At each sample time data points with the same superscript are not significantly different $(\mathrm{P}>0.05), \mathrm{n}=23-29$.

FIG. 4. Scanning electron micrographs of (a) and (b) the surface of a typical Atlantic salmon ovum displaying protein plugs sealing the pore channels of the zona radiata (scale bar $=40 \mu \mathrm{m}$ and $25 \mu \mathrm{m}$ respectively), (c) the micropyle of a typical Atlantic salmon ovum (scale bar $=15 \mu \mathrm{m}$ ), (d) a damaged Atlantic salmon ovum displaying blister-like holes in the chorion $($ scale bar $=150 \mu \mathrm{m})$ and, (e) a damaged Atlantic salmon ovum displaying the detail of a blister-like hole in the chorion (scale bar $=15 \mu \mathrm{m}$ ). 


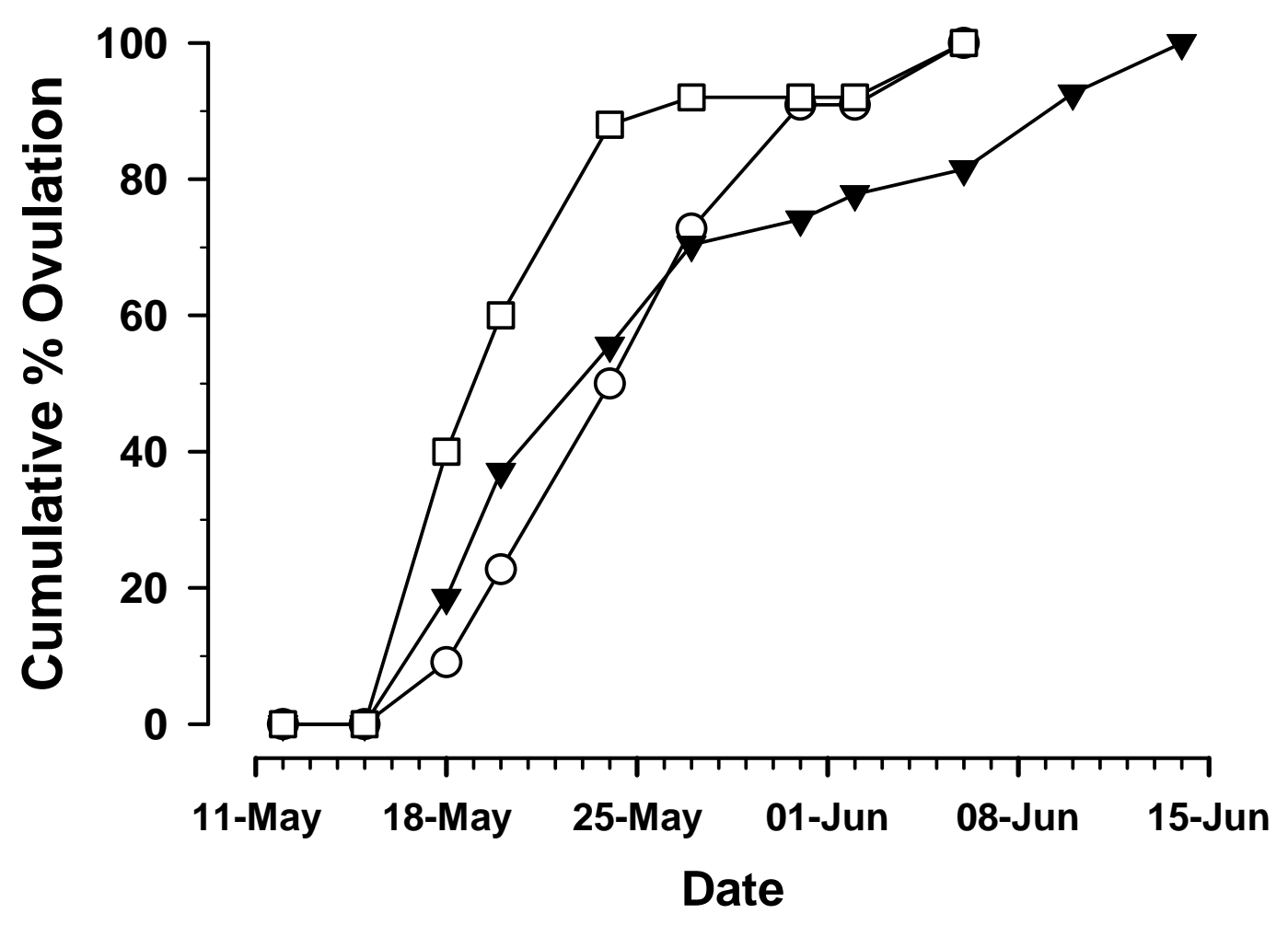



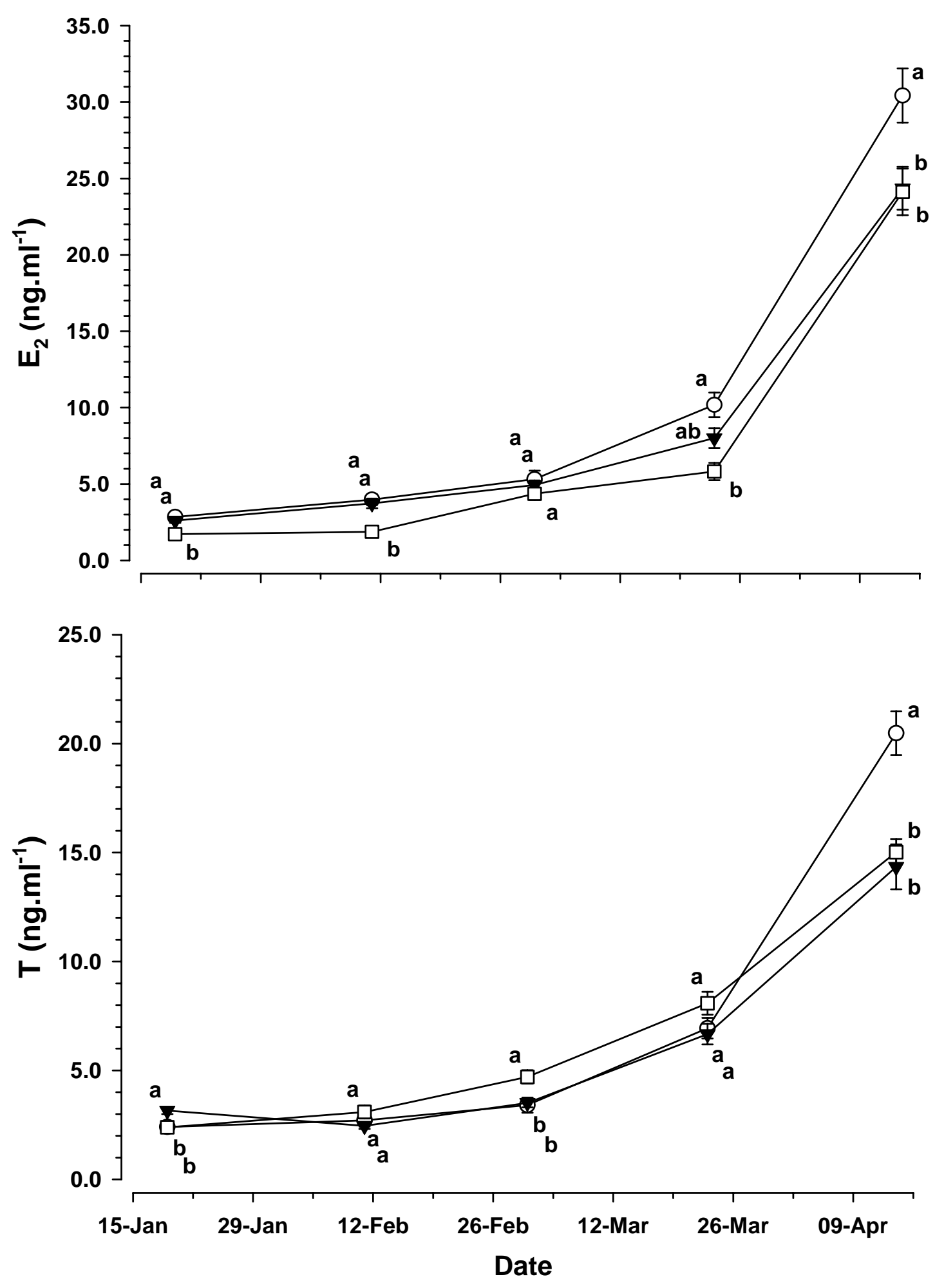

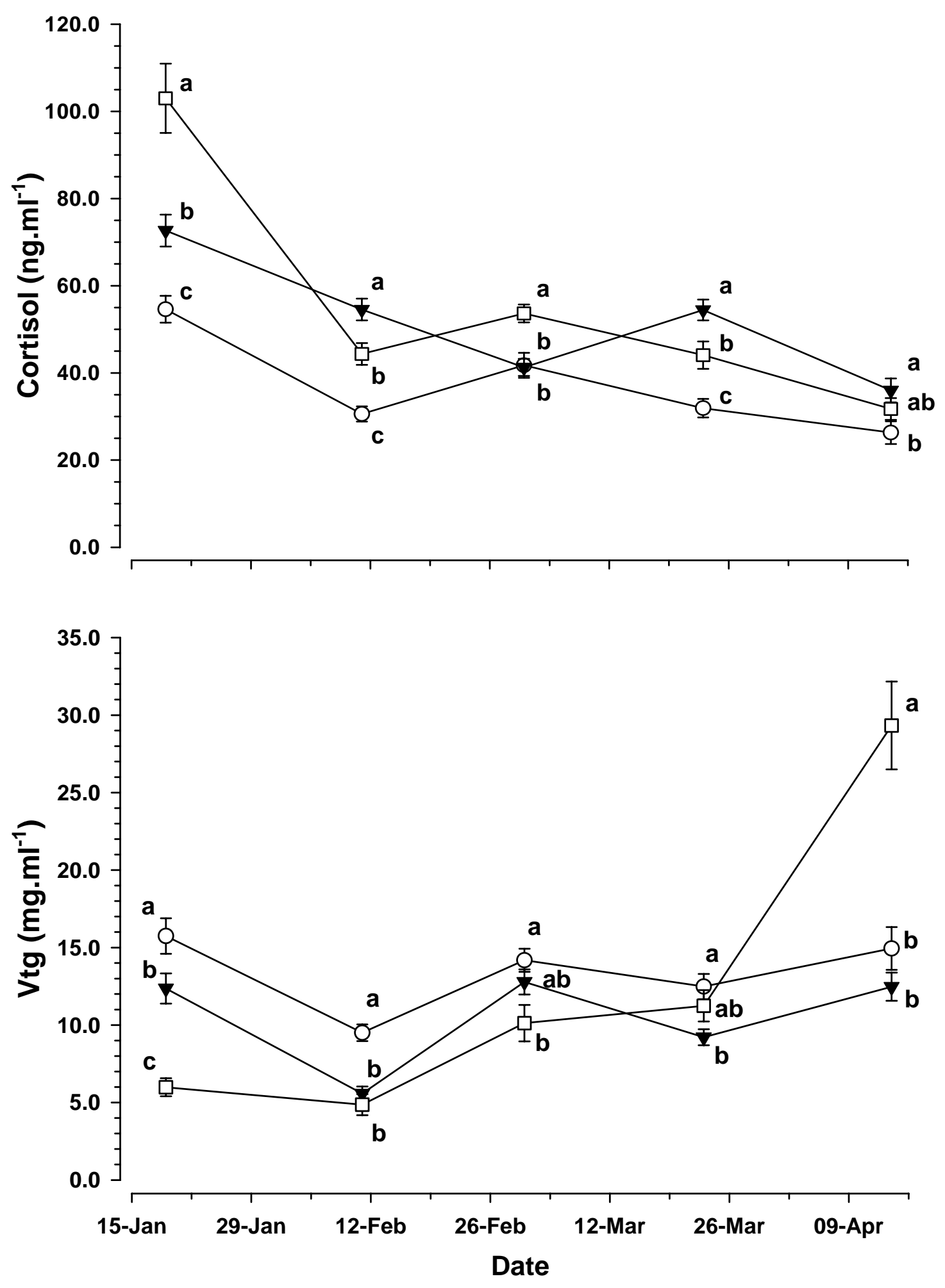